\section{Development of a Strip Seeder for Converting Cool-season Turf to Seeded Bermudagrass}

\author{
Jack Fry ${ }^{1,5}$, Randy Taylor ${ }^{2}$, Bob Wolf ${ }^{3}$, Dick Stuntz ${ }^{4}$, \\ and Alan Zuk ${ }^{1}$
}

AdDitional INDEX wORDs. Cynodon dactylon, establishment, Lolium perenne, perennial ryegrass, warm-season grasses

SUMMARY. Turfgrass managers in the transition zone are interested in converting swards of cool-season grasses to cold-hardy seeded bermudagrass (Cynodon dactylon) in an effort to reduce water and fungicide inputs. The objective of this study was to evaluate the potential for establishing 'Riviera' bermudagrass in a perennial ryegrass (Lolium perenne) sward by using a strip-seeding technique, and then to build a machine that would facilitate the process. Four, 2 -inch-wide tilled rows, 1 inch deep and 15 inches apart, were created in $6 \times 6$-ft plots and seeded by hand with 'Riviera' bermudagrass at $104 \mathrm{lb}$ /acre pure live seed in July 2002. In one set of strip-seeded plots, a 7 -cm-wide overspray of glyphosate $(\approx 0.5$ inch on either side of the row) was applied over tilled rows after seeding to suppress perennial ryegrass further. Plots established by the strip-seeding technique exhibited $71 \%$ bermudagrass coverage after two growing seasons, and $87 \%$ coverage when rows received a glyphosate overspray. Broadcasting 'Riviera' seed into perennial ryegrass plots resulted in $60 \%$ bermudagrass coverage at the end of the second season of establishment. A strip seeder was constructed and used to seed 'Riviera' into existing perennial ryegrass turf in late July 2004 using the aforementioned row configurations and a glyphosate overspray. Coverage evaluated the following spring, before green-up, was $10.3 \%$ compared with $0 \%$ coverage where 'Riviera' was broadcast seeded. At the seeding rates evaluated, $79 \%$ less 'Riviera' bermudagrass seed was required when using the strip-seeding method, and golfers would consider the surface more amenable to play during the establishment period compared with broadcasting glyphosate and seed. A patent is pending on the strip-seeding equipment and establishment process.

$\mathrm{W}$ ith the cost of maintaining cool-season sports turfs increasing in the transition zone as a result of expenses associated with water and fungicide applications, there is interest in converting these areas to freezing-tolerant warmseason grasses (Zuk and Fry, 2005). Bermudagrass is used extensively in the transition zone, but until recently there were no seeded turf-type cultivars that had acceptable freezing tolerance. 'Yukon' bermudagrass was

\footnotetext{
Thanks are extended to Johnston Seed Company, Enid, Okla., for providing 'Riviera' bermudagrass seed, and to the Kansas Turfgrass Foundation for partial support of this project.

This is contribution no. 06-87-5 from the Kansas Agr. Exp. Sta., Manhattan, Kan.

${ }^{1}$ Department of Horticulture, Forestry and Recreation Resources, Kansas State University, 2021 Throckmorton, Manhattan, KS 66506

${ }^{2}$ Department of Biosystems and Agricultural Engineering, Oklahoma State University, Stillwater, OK 74078

${ }^{3}$ Department of Biological and Agricultural Engineering, Kansas State University, Manhattan, KS 66506

${ }^{4}$ Alvamar Inc., 2021 Crossgate Drive, Lawrence, KS 66047

${ }^{5}$ Corresponding author. E-mail: jfry@ksu.edu.
}

released in 2002 by Oklahoma State University (Taliaferro et al., 2004) and 'Riviera' was released soon thereafter; both were developed with improved freezing tolerance as a primary consideration. Converting an existing stand of perennial ryegrass to a seeded bermudagrass would commonly be done by treating the perennial ryegrass sward with a nonselective herbicide before seeding bermudagrass. This may require that the area be closed during the establishment period, however, resulting in a significant loss of revenue at some facilities, such as golf courses. In addition, costs associated with purchase of herbicide and seed may be prohibitive for some operations.

To avoid the expense associated with sodding golf course fairways and tees, Meyer zoysiagrass (Zoysia japonica), another warm-season turfgrass used extensively in the transition zone, is routinely strip sodded into cool-season golf course fairways. During this process, zoysiagrass strips measuring 6 to 12 inches wide are laid into voids of the same width that have been cut in the existing cool-season turf, and spaced anywhere from 1 to 2 $\mathrm{ft}$ apart; closer spacing results in faster zoysiagrass coverage (Dunn et al., 2000). The strip-sodding process can be accomplished in a matter of days, and the golf course is then open for play. Hence, establishment costs are minimized and there is little interruption in golf course revenue flow.

After strip sodding is completed, the area is managed to favor zoysiagrass cultural requirements. Complete zoysiagrass coverage can usually be expected over a period of 2 or 3 years (Dunn et al., 2000). Past successes with strip sodding zoysiagrass on golf courses, and the release of freezingtolerant seeded bermudagrass cultivars, led us to consider the use of strip seeding to convert a stand of perennial ryegrass to bermudagrass.

Our objective was to evaluate the potential for converting a sward of perennial ryegrass to 'Riviera' bermudagrass in small plots, and then to develop equipment that would facilitate this conversion on a larger scale.

\section{Materials and methods}

EVALUATING STRIP SEEDING AS AN ESTABLISHMENT METHOD. This experiment was conducted at the Rocky Ford Turfgrass Research Field near Manhattan, Kan. Soil was a

\begin{tabular}{lllc}
\hline $\begin{array}{l}\text { Units } \\
\text { To convert U.S. to SI, } \\
\text { multiply by }\end{array}$ & U.S. unit & SI unit & $\begin{array}{l}\text { To convert SI to U.S., } \\
\text { multiply by }\end{array}$ \\
\hline 0.4047 & $\mathrm{acre}(\mathrm{s})$ & $\mathrm{ha}$ & $2.471 \mathrm{l}$ \\
0.3048 & $\mathrm{ft}$ & $\mathrm{m}$ & 3.2808 \\
0.0929 & $\mathrm{ft}^{2}$ & $\mathrm{~m}^{2}$ & 10.7639 \\
9.3540 & $\mathrm{gal} / \mathrm{acre}$ & ${\mathrm{L} \cdot \mathrm{ha}^{-1}}$ & 0.1069 \\
2.5400 & inch(es) & $\mathrm{cm}$ & 0.3937 \\
25.4000 & inch(es) & $\mathrm{mm}$ & 0.0394 \\
0.4536 & $\mathrm{lb}$ & $\mathrm{kg}$ & 2.2046 \\
1.1209 & $\mathrm{lb} / \mathrm{acre}$ & $\mathrm{kg} \cdot \mathrm{ha}^{-1}$ & 0.8922 \\
28.3495 & $\mathrm{oz}$ & $\mathrm{g}$ & 0.0353 \\
6.8948 & $\mathrm{psi}$ & $\mathrm{kPa}$ & 0.1450
\end{tabular}


Chase silt loam (fine, montmorillonitic, mesic Aquic Arguidolls) with a $\mathrm{pH}$ of 7.2 and $4 \%$ organic matter. The existing perennial ryegrass turf was a dense 3-year-old blend of equal parts 'Charger II', 'Manhattan 3', 'Brightstar', and 'Roadrunner'. Plots measured $6 \times 6 \mathrm{ft}$ and were arranged in a randomized complete-block design with four replicates. Treatments imposed on the perennial ryegrass sward were broadcast bermudagrass seed, glyphosate broadcast + broadcast bermudagrass seed, and planting bermudagrass in rows to mimic those that would be created by a strip seeder, with and without a glyphosate overspray on each row. 'Riviera' bermudagrass seed was obtained from Johnston Seed Co. (Enid, Okla.). The label indicated that purity was $51 \%$ and germination $85 \%$; hence, the pure live seed (PLS) contained was $43 \%$. For the nonselective broadcast treatment, glyphosate was applied in a $2 \%$ solution 1 week before planting by using a Solo backpack sprayer (model no. 475; Solo, Newport News, Va.) to eradicate all vegetation.

Before seeding, all plots except those to be established by strip seeding were core aerified and verticut. Cores were pulled on 4 -inch centers and measured 0.5 inch in diameter and 0.5 to 1.5 inches deep. After aerification, a verticutter with blades on $9.5-\mathrm{cm}$ spacing was used in two directions over each study area to break up cores and create 3 -mm-deep slices in the soil surface.

On 2 July 2002, bermudagrass seed was mixed with $300 \mathrm{~g}$ natural organic fertilizer $6 \mathrm{~N}-0.9 \mathrm{P}-0 \mathrm{~K}$ (Milorganite, Milwaukee, Wisc.) and spread by using a shaker bottle to provide PLS at $66 \mathrm{lb} /$ acre and $\mathrm{N}$ at $49 \mathrm{lb} /$ acre.

Planting rows to mimic those that would be created by a strip seeder were created by modifying a slit seeder (Fig. 1). Existing vertically operating knives were removed and replaced with four knives attached to a horizontal crank shaft. Knives had teeth extending obliquely from their perimeter. The unit was operated by using the power takeoff on a tractor and, when set on the soil surface, the knives created four 2inch-wide tilled rows, 1 inch deep, 15 inches apart, the entire length of each plot. This resulted in disturbance of $\approx 4 \mathrm{ft}^{2}$ in each plot $(11 \%$ of the

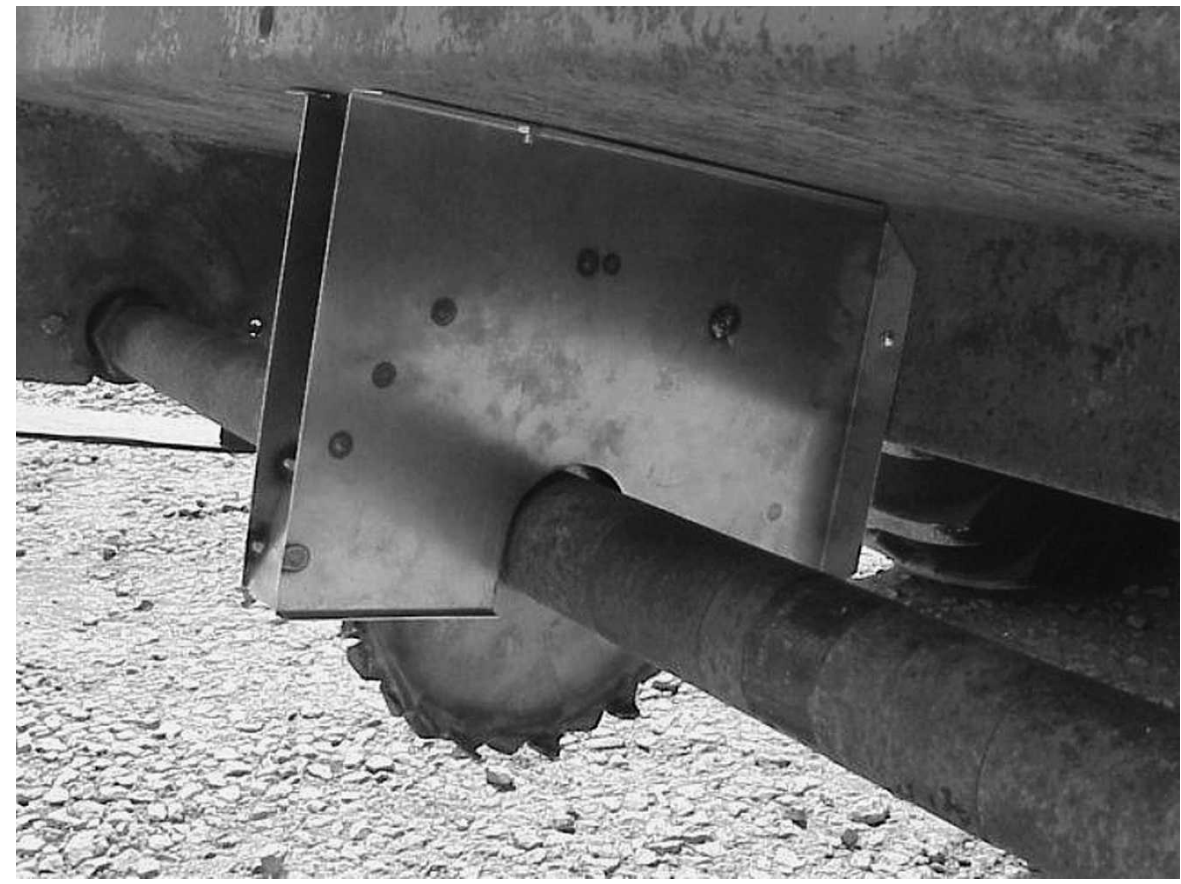

Fig. 1. One of four rotating tiller blades mounted on a modified seeder and used to create the 2 -inch-wide $(5.1-\mathrm{cm})$ strip-seeded rows in $6 \times 6$-ft $(1.8-\mathrm{m})$ perennial ryegrass plots and to evaluate conversion to seeded 'Riviera' bermudagrass.

entire plot area). 'Riviera' bermudagrass seed was mixed with Milorganite (same rate of $\mathrm{N}$ application as in other treatments) to apply PLS at 104 $\mathrm{lb} / \mathrm{acre}$ in rows. A shaker bottle was modified to include a 60 -mm-diameter tube in its lid to deliver the seedMilorganite mixture in a narrow row. A hand-held press wheel the same width as the seeded rows was used to firm the surface after seeding. Immediately after seeding, a 7-cmwide band of glyphosate was applied over the rows in one of the strip seeding treatments to eliminate perennial ryegrass up to 0.5 inch on either side of the row using the same sprayer and application method described previously.

Beginning the day after seeding, irrigation was applied two to three times daily during the first 4 weeks to provide a total of $\approx 3 \mathrm{~mm}$ of water in each session. After 4 weeks, $3 \mathrm{~mm}$ of water was applied every $2 \mathrm{~d}$ when rainfall was not adequate. A reel mower was used to cut the study area $3 \mathrm{~d}$ weekly at $0.5 \mathrm{inch}$. Nitrogen from urea $(46 \mathrm{~N}-0 \mathrm{P}-0 \mathrm{~K})$ was applied at $44 \mathrm{lb} /$ acre on 10 July and on $\mathrm{l}$ and 22 Aug. 2002. In 2003, irrigation was again applied every $2 \mathrm{~d}$ as needed, as described for 2002. Mowing was the same as in 2002. Nitrogen from urea was applied at $66 \mathrm{lb} /$ acre on 2 and
23 June, and 14 July, and at $44 \mathrm{lb} /$ acre on 4 Aug. Data were collected on bermudagrass coverage and turfgrass quality. The vertical-point quadrant method (Gaussoin and Branham, 1989) was used to determine bermudagrass coverage within each treatment plot after growth had ceased in October. The vertical-point quadrant was constructed of a polyvinylchloride frame measuring $6 \times 6 \mathrm{ft}$ with an internal monofilament grid spaced on 4 -inch centers, allowing for 324 intersections. The grid was placed over each plot to estimate coverage in each treatment. The presence of any part of a bermudagrass plant under an intersection was recorded as a "hit." To determine percentage of coverage, the number of hits was divided by 324 and multiplied by 100. Photographs of plots established using strip seeding with a glyphosate overspray were taken when bermudagrass was dormant in October of each year (Fig. 2.)

To determine the impact of establishment treatments on turfgrass quality the first 2 months after seeding, visual ratings were taken weekly in July and Aug. 2002, and monthly averages were determined. Quality was rated on a 0 to 9-point scale, where 7 points is acceptable quality for a golf course fairway. Data were 

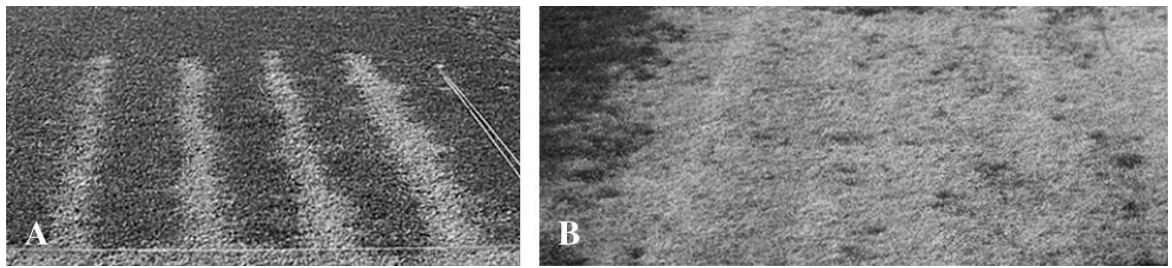

Fig. 2. 'Riviera' bermudagrass coverage resulting from strip seeding into perennial ryegrass and then applying a 7 -cm-wide $(2.8$-inch $)$ band of glyphosate over each row. Dormant, straw-brown bermudagrass is shown at the end of 2002 (A), and in the same plot at the end of 2003 (B). analyzed according to the SAS (SAS Institute, Cary, N.C.) analysis of variance procedure to test for treatment effects. Means were separated by using Tukey's LSD test at $P<0.05$.

STRIP SEEDER DEVELOPMENT AND EVALUATION. In 2003, a strip seeder was assembled in the Department of Biological and Agricultural Engineering at Kansas State University (Fig. 3). The strip seeder is capable of creating six rows, $\approx 2$ inches wide, using similar tilling devices used during the initial evaluation. A seed-fertilizer mixture is retained in seed hoppers and is then deposited on the surface of the tilled row. A press wheel firms the row and then a glyphosate spray solution, originating from a tank mounted on the unit, is applied over the surface of the row to suppress perennial ryegrass up to 1 inch on either side of the row.
On 21 July 2004, the strip seeder was used on a 3-year-old dense stand of perennial ryegrass at the Rocky Ford Turfgrass Research Center with the same soil characteristics as described for the previous study. Plots measured $6 \times 10 \mathrm{ft}$ and were arranged in a randomized complete block with three replicates. 'Riviera' bermudagrass was planted by using a traditional broadcast method or the strip seeder. In broadcast-seeded plots, no seedbed preparation was done before applying a seed and Milorganite mixture with a shaker bottle to provide PLS and $\mathrm{N}$ at $66 \mathrm{lb} /$ acre. 'Riviera' bermudagrass was mixed with an organic fertilizer in a 7 Milorganite : 1 seed mixture and placed in the seed hopper. This provided fertilizer and seed application rates in the strip-seeded rows that were identical to those for the

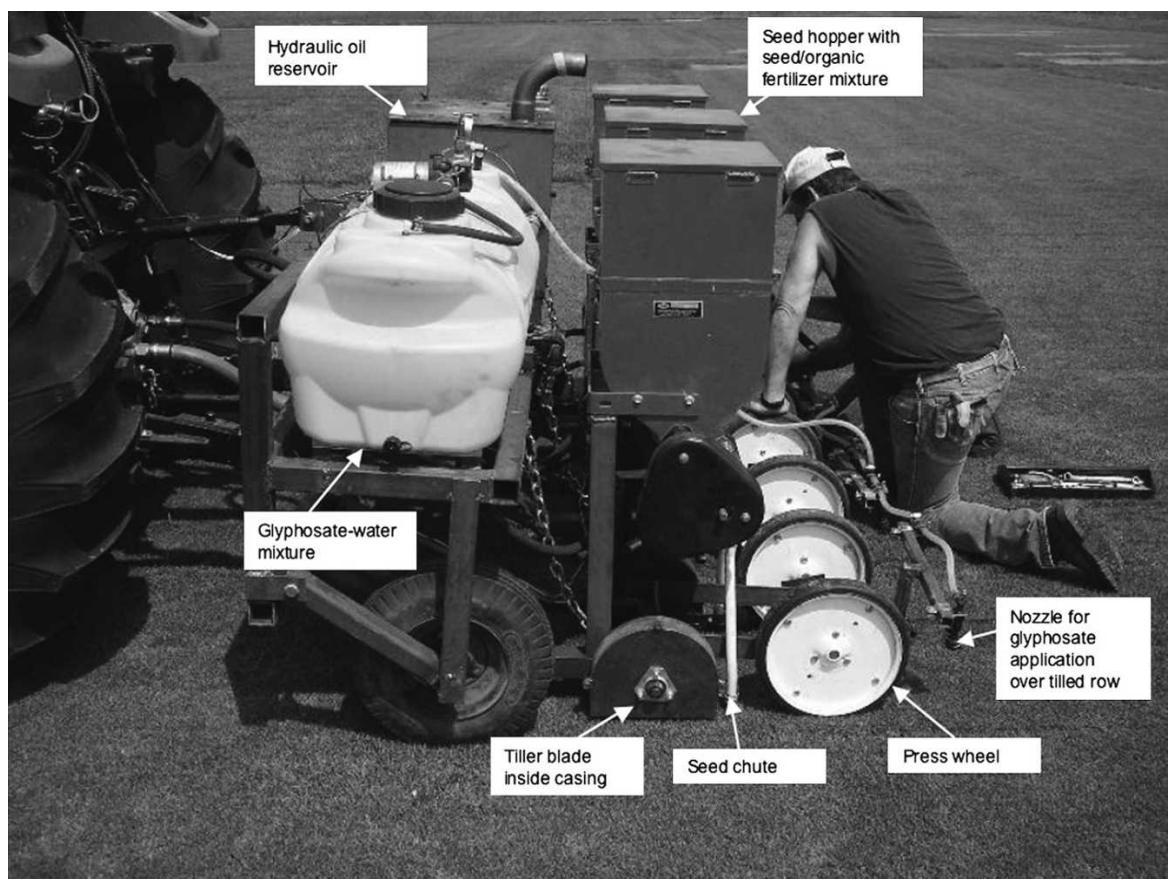

Fig. 3. The strip seeder and its components that were used to convert a perennial ryegrass turf to seeded 'Riviera' bermudagrass. broadcast treatment. Four stripseeded rows were planted in each plot by using the strip seeder; glyphosate ( $2 \%$ solution) was applied over each at the same rate used in the small plot evaluation, but using the seedermounted spray unit to apply $2 \mathrm{gal} /$ acre at a pressure of 22 psi through 6501 flat-fan nozzles (Spraying Systems Co., Wheaton, Ill.).

After planting, the study area was mowed $3 \mathrm{~d}$ weekly at 0.5 inch. Irrigation was applied several times daily during the bermudagrass emergence period ( $\approx 2$ weeks). Thereafter, irrigation was applied to maintain a moist seedbed. A second application of $\mathrm{N}$ from urea was made at $66 \mathrm{lb} /$ acre on 27 Aug.

A visual estimate of bermudagrass coverage in each plot was made on 7 Apr. 2005 before spring greenup. Data were analyzed according to the SAS to test for treatment effects. Means were separated using Tukey's LSD test at $P<0.05$.

\section{Results and discussion}

Evaluating STRIP SEEDING AS an establishment method. Perennial ryegrass plots that were broadcast seeded with 'Riviera' had 12\% bermudagrass coverage at the end of the first year and $60 \%$ coverage at the end of the second (Table 1). Complete bermudagrass coverage the first season was attained by using a broadcast glyphosate application followed by broadcasting bermudagrass seed. Visual observations indicated that complete coverage had occurred within 4 to 5 weeks after seeding (data not shown).

The strip-seeding method, although disturbing only $11 \%$ of the plot area at planting, resulted in $41 \%$ bermudagrass coverage by Oct. 2002 and $71 \%$ coverage by Oct. 2003 (Table 1, Fig. 2). Applying glyphosate over rows resulted in an additional loss of $11 \%$ of the perennial ryegrass, and about $15 \%$ greater coverage in 2002 and 2003, compared with coverage in strip-seeded rows without a glyphosate overspray. After bermudagrass coverage exceeds $80 \%$, the turfgrass manager could remove the remaining perennial ryegrass with a broadcast application of glyphosate over dormant bermudagrass.

Bermudagrass establishment using the strip-seeding method was successful, in part because it created space, 
Table 1. Influence of establishment method on 'Riviera' bermudagrass coverage in a perennial ryegrass turf at the end of the 2002 and 2003 growing seasons in Manhattan, Kan.

\begin{tabular}{|c|c|c|}
\hline \multirow[b]{2}{*}{ Treatment } & \multicolumn{2}{|c|}{$\begin{array}{l}\text { Bermudagrass coverage } \\
(\% \text { of plot area })^{\mathrm{z}}\end{array}$} \\
\hline & October 2002 & October 2003 \\
\hline Broadcast seeded & $12 \mathrm{~d}^{\mathrm{y}}$ & $60 \mathrm{c}$ \\
\hline Glyphosate broadcast + broadcast seeded & $100 \mathrm{a}$ & $100 \mathrm{a}$ \\
\hline Strip seeded ${ }^{\mathrm{x}}$ & $41 \mathrm{c}$ & $71 \mathrm{bc}$ \\
\hline Strip seeded + glyphosate overspray & $56 \mathrm{~b}$ & $87 \mathrm{ab}$ \\
\hline
\end{tabular}

${ }^{2}$ Coverage was determined when bermudagrass was dormant using a vertical-point quadrant method. Numbers represent the mean of four replications.

${ }^{y}$ Means followed by the same letter in a column are not statistically different $(P<0.05)$.

${ }^{x}$ The strip seeder created four 2 -inch-wide $(5.1-\mathrm{cm})$ rows 15 inches $(38.1 \mathrm{~cm})$ apart in each plot. The glyphosate overspray in strip seeder plots was used to eliminate perennial ryegrass up to 0.5 inches $(1.27 \mathrm{~cm})$ on either side of each row.

'Riviera' bermudagrass was seeded to provide pure live seed at $66 \mathrm{lb} / \mathrm{acre}\left(74.0 \mathrm{~kg} \cdot \mathrm{ha}^{-1}\right)$ in broadcast-seeded and glyphosate broadcast + broadcast-seeded plots on 2 July 2002, after core aerating and verticutting.

or a gap, that allows the seedling to emerge and develop without the competition of surrounding perennial ryegrass plants. The importance of gap size in emergence and development of a warm-season grass in coolseason turf has been previously demonstrated. The summer annual grassy weed crabgrass (Digitaria spp.) was more abundant and grew larger when gap sizes in cool-season turf increased (Kim et al., 1998). Converting sodforming cool-season grasses, such as kentucky bluegrass (Poa pratensis) or creeping bentgrass (Agrostis stolonifera), using the strip-seeding method has not been evaluated. The ability of these grasses to spread laterally would likely create more competition for seeded bermudagrass and affect the establishment rate.

At the seeding rates evaluated herein, a seed savings of $79 \%$ would have been realized by using the strip seeder versus the broadcast method. At the time the study was done, 'Riviera' bermudagrass seed cost was $\$ 27.90 / \mathrm{lb}$ PLS. At these seeding rates, using the strip seeder instead of a broadcast method would result in a savings of nearly $\$ 1600 /$ acre. Savings also would have been realized in glyphosate and labor involved in aerification and verticutting before seeding. In a golf course setting, stripseeded turf could be played on shortly after seeding. Restricting carts from these areas would be necessary because traffic can greatly reduce establishment success of seeded warmseason grasses (Zuk and Fry, 2005). Local rules would have to be implemented for occasions when a ball comes to rest on a seeded row.
Strip seeding 'Zenith' zoysiagrass at $75 \mathrm{lb} /$ acre into 3 -inch-wide glyphosate-treated strips, spaced $1 \mathrm{ft}$ apart, resulted in $73 \%$ coverage by the end of the third season of establishment in Kansas (Zuk and Fry, 2005). Bermudagrass is more aggressive than zoysiagrass, and we observed that more than $80 \%$ coverage was achieved in two seasons by using 2 -inch-wide rows spaced 15 inches apart. Successful establishment of zoysiagrass using strip seeding in small plots suggest that this species may also be a candidate for conversion of perennial ryegrass turfs using the strip seeder.

Differences in turf quality were observed among all treatments during July 2002. Poorest quality was observed in plots where glyphosate was used over entire plots (quality, 1.1 points) or over rows created by the strip seeder (quality, 3.5 points). By Aug. 2002, bermudagrass had completely covered glyphosate-treated perennial ryegrass plots and acceptable quality was observed. Similarly, strip-seeded plots over which glyphosate had been applied also exhibited acceptable quality by August. Use of the strip seeder without glyphosate also resulted in unacceptable quality in July 2002 (quality, 5.9 points) but recovery occurred by August (quality, 7.1 points). In general, treatments that resulted in the greatest reduction in perennial ryegrass quality provided the best bermudagrass establishment by the end of the season.

Although initial quality was better in strip-seeded turf than in glyphosate broadcast-treated turf, one would expect a less uniform appearance to persist for a longer period of time in strip-seeded turf. In autumn and early spring, strip-seeded turf has a nonuniform striped appearance when bermudagrass is dormant, and surrounding perennial ryegrass remains green. Some may consider this striping objectionable.

STRIP SEEDER DEVELOPMENT AND EVAluAtion. In Apr. 2005, after strip seeding on 21 July 2004, there was no visible bermudagrass coverage in broadcast-seeded plots. This was a significantly $(P<0.05)$ lower coverage than that observed in plots established using the strip-seeding technique (10.3\% coverage). Bermudagrass sustained winter injury, which precluded further evaluation of coverage through 2005. This first attempt at strip seeding revealed a few problems with the process that need to be resolved. For example, hydraulic power to some of the tilling units was insufficient, which occasionally caused them to stall. In addition, the nozzles that delivered the glyphosate application were mounted slightly higher than desired, causing a wider application band than preferred.

After the initial strip seeder evaluation, the equipment was sold to a company that intends to use it to assist turf managers in converting coolseason turfgrass stands to seeded bermudagrass and zoysiagrass. In June 2006, the River Oaks Golf Course in Grandview, Mo., was strip seeded with 'Riviera' bermudagrass using the same seeder described herein. The course remained open for play after seeding, and by Oct. 2006, most fairways exhibited more than $60 \%$ bermudagrass coverage. A U.S. patent is pending on the strip-seeding method and equipment (Fry et al., 2005).

In summary, two primary advantages converting a perennial ryegrass stand to seeded bermudagrass by strip seeding are 1) there is little interruption in use of the turf, and on a golf course this would allow for revenue flow to continue during the conversion process; and 2 ) as much as $80 \%$ less seed (on a weight basis) is required, compared with converting the perennial ryegrass turf by broadcasting bermudagrass seed, and savings are also realized on other practices associated with seedbed preparation before a broadcast application of seed. Those who would like more information about using a strip seeder for converting cool-season turf to seeded 
warm-season grasses should contact Topeka Sod Farm, 6506 Cherokee Lane, Ozawkie, KS 66070. Phone: (785) 979-4078.

\section{Literature cited}

Dunn, J.H., E.H. Ervin, and B.S. Fresenburg. 2000. Establishment and care of zoysia lawns. Univ. Missouri Ext. Serv., Columbia, Mo., Publ. G6706.

Fry, J., R. Taylor, R. Wolf, and R. Stuntz. 2005. Method and equipment for inter- seeding an area of ground to convert the existing vegetation to new vegetation or to improve the quality of the existing vegetation. U.S. patent application 20060016375. U.S. Patent and Trademark Office, Washington, D.C.

Gaussoin, R.E. and B.E. Branham. 1989. Influence of cultural factors on species dominance in a mixed stand of annual bluegrass / creeping bentgrass. Crop Sci. 29:480-484.

Kim, T.J., F.S. Rossi, and J.C. Neal. 1998. Effects of physical disturbance on crabgrass encroachment in cool season turf.
Agron. Abstr., 1998 Annu. Meeting of the Amer. Soc. of Agron., Crop Science Soc. of Amer., and Soil Science Soc. of Amer., Baltimore, Md, Oct. 18-22. p. 133. Amer. Soc. of Agron., Madison, Wis.

Taliaferro, C.M., D.L. Martin, J.A. Anderson, M.P. Anderson, G.E. Bell, and A.C. Guenzi. 2004. Registration of 'Yukon' bermudagrass. Crop Sci. 43: 131-132.

Zuk, A. and J. Fry. 2005. Seeded zoysiagrass establishment in a perennial ryegrass sward. Crop Sci. 45:1521-1528. 